\title{
Notes on the stratigraphy, extent and tectonic implications of the Minkinfjellet Basin, Middle Carboniferous of central Spitsbergen
}

\author{
WINFRIED K. DALLMANN
}

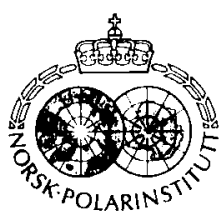

\begin{abstract}
Dallmann, W. 1993: Notes on the stratigraphy, extent and tectonic implications of the Minkinfjellet Basin, Middlc Carbonifcrous of central Spitsbergen. Polar Research 12.(2), 153-160.

A part of the Carboniferous basin stratigraphy, the clastic to carbonaceous Minkinfjellet "Member" of the Nordenskiöldbreen Formation in Central Spitsbergen, is deposited in an asymmetric basin structure (here referred to as the Minkinfjellet Basin), similar to the underlying Ebbadalen Formation. The western boundary - situated within the Billefjorden Fault Zone - has probably been a little farther east than during deposition of the Ebbadalen strata. The thickness attains ca. $350 \mathrm{~m}$ in central parts of the basin, and the strata strongly attenuates to the east and south. The base and top are interpreted as low-angle stratigraphical unconformities. The boundary with the overlying Cadellfjellet Member of the Nordenskiöldbreen Formation is locally disrupted by carbonate breccias of suggested earthquakc origin. Formation rank is suggested for the sedimentary succession of the Minkinfjellet basin.
\end{abstract}

W. K. Dallmann, Norsk Polarinstitut, Middelthuns gate 29, P.O. Box 5072 Majorstua, N-030I Oslo, Norway.

\section{Introduction}

During recent regional geology mapping in central Spitsbergen for Norsk Polarinstitutt (Dicksonfjorden map sheet, Dallmann et al. in prep.). I came across some peculiarities within the Middle Carboniferous strata of the area around northern Billefjorden. Some of these observations are controversial to the previously published stratigraphic frame. especially concerning the distinction of the mainly Bashkirian Ebbadalen Formation and the mainly Moscovian Minkinfjellet "Member" (Gee et al. 1953; Cutbill \& Challinor 1965; Lauritzen et al. 1989; Johannessen \& Steel 1992). Furthermore, some stratigraphical, lithological and geometric observations in the Minkinfjellct strata stimulated some thoughts about the basin-related development of the succession. As time did not permit detailed logging or sampling during this mapping work. I hope that this notc will encourage others to consider carrying out a more thorough investigation of this hitherto sparsely described part of the Carboniferous of Svalbard.

\section{Stratigraphic confusion (Table 1)}

The term "Minkinfjellet Member" describing the lower part of the Nordenskiöldbreen Formation (Moscovian to Late Carboniferous) was introduced by Cutbill \& Challinor (1965). It is meant to comprise a succession of sandstones, limestones, carbonate breccias and local evaporites, stratigraphically situated between the evaporitic Ebbadalen Formation ("Lower
Gypsifcrous scries", Gee et al. 1953) and the overlying part of the Nordenskiöldbreen Formation ("Cyathophyllum Limestone". Nordenskiöld 1875). It occurs only to the east of the Billefjorden Fault Zone (Fig. 1), though approximately coeval strata (Scheteligfjellet Member, ?Tårnkanten Formation) are exposed at some distance to the west.

The Minkinfjellet "Member" was earlier named the "Passage Beds" (Wordie 1919). Gee et al. (1953) tentatively correlated the Passage Beds with a multicoloured sandstone-conglomerate succession at the mountain Pyramiden which they named the "Pyramiden conglomerates" according to the earlier described "Pyramiden conglomerate Formation" (Ljutkevic 1937) or "Pyramiden Formation" (Ustrickij 1967) (Fig. 2). Later stratigraphical work by Gjelberg \& Steel (1981), Johannessen (1980) and Johannessen \& Stecl (1992), however, placed much of the "Pyramiden conglomerates" into the Ebbadalen Formation and explained them as lateral equivalents to the Ebbadalen evaporites, situated in a proximal setting close to the Billefjorden Fault zone (Odellfjellet Member of the Ebbadalen Formation). The stratigraphic relation between the conglomeratic and the evaporatic parts of the Ebbadalen Formation (Tricolorfjellet Member) can be observed farther north at the mountains Tricolorfjellet and Odellfjellet (north of Fig. 1 map area). Still, on the geological map sheet Billefjorden (Lauritzen et al. 1989), these conglomerates are grouped with the Minkinfjellet "Member", unfortunately without discussing the reason.

Another name. "Elsabreen conglomerate beds" was used by Cutbill \& Challinor (1965). These beds were defined at the northern side of Pyramiden, but mean probably the same succession as "Pyramiden conglomerates". Since Cutbill \& Chal- 
Table 1 . Stratigraphic names used in the geological literature related to the discussed succession.

\begin{tabular}{|c|c|c|c|}
\hline Gee et al. 1953 & Cutbill \& Challinor 1965 & $\begin{array}{l}\text { Johannessen } 1980 \\
\text { Johannessen \& Steel } 1992\end{array}$ & proposed here \\
\hline $\begin{array}{l}\text { Cyathophyllum Limestones } \\
\text { (Wordiekammen Limestones } \\
\text { of Forbes et al. 1958) }\end{array}$ & $\begin{array}{l}\text { Nordenskiöldbreen Formation } \\
\text { Tyrrellfjellet Member } \\
\text { Cadellfjellet Member }\end{array}$ & $\begin{array}{l}\text { Nordenskiöldbretn Formation } \\
\text { Tyrrellfjellet Member } \\
\text { Cadellfjellet Member }\end{array}$ & $\begin{array}{l}\text { Nordenskiöldbreen Formation } \\
\text { Tyrrellfjellet Member } \\
\text { Cadellfjellet Member }\end{array}$ \\
\hline $\begin{array}{l}\text { Campbellryggen Group } \\
\text { Passage beds }\end{array}$ & \multirow[t]{2}{*}{$\begin{array}{l}\text { Minkinfjellet Member } \\
\text { Anservika beds } \\
\text { Carronelva beds } \\
\text { Pyramiden beds } \\
\text { Elsabreen beds }\end{array}$} & Minkinfjellet Member & $\begin{array}{l}\text { Minkinfjellet Formation } \\
\text { Fortet Member } \\
\text { Anservika Member } \\
\text { Carronelva Member } \\
\end{array}$ \\
\hline & & Ebbadalen Formation & Ebbadalen Formation \\
\hline Lower Gypsiferous Series & Ebbadalen Formation & $\begin{array}{l}\text { Odellfjellet Member } \\
\text { Tricolorfjellet Member } \\
\text { Ebbaelva Member }\end{array}$ & $\begin{array}{l}\text { Odellfjellet Member } \\
\text { Tricolorfjellet Member } \\
\text { Elsabreen Member }\end{array}$ \\
\hline
\end{tabular}

linor do not describe but only mention the latter, a distinction cannot be made.

In the top area of the Pyramiden mountain, the "Pyramiden conglomerates" are overlain by a light-grey sandstone succession of approximately $100 \mathrm{~m}$ thickness ( $\mathrm{EO}_{2}$ on Fig. 2), which in return is overlain by limestones of the Nordenskiöldbreen Formation (Cadellfjellet Member). This sandstone succession has by previous authors (e.g. Lauritzen et al. 1989; Johannessen \& Steel 1992) been considered as part of the Minkinfjellet "Member".

According to my observations, however, these sandstones bend eastward down, where they form the lower part of the eastern slopes of the mountains Pyramiden, Mumien and Svenbrehøgda, and where they are overlain by a thin multicoloured succession. The latter is stratigraphically upward followed by thick evaporites with limestone intercalations lithologically very similar to the gypsiferous Tricolorfjellet Member. Except for the presence of the light sandstones, the stratigraphical relations seem thus to be very similar to those at Tricolorfjellet (Johannessen \& Steel 1992, fig. 8), though they are not so casily observed because of strong faulting and downwarping in the Petuniabukta area related to both Carboniferous and Tertiary tectonism (Harland et al. 1974). Consequently, the light-grey sandstones. both these near the mountain top and those on the slope, are thought to represent a local facies between the interfingering Odellfjellet and Tricolorfjellet Members. They are tentatively grouped with the Odellfjellet Member on Fig. 2. I am tending to assume that no Minkinfjellet strata exist at all in the Pyramiden area or west of Petuniabukta.

\section{Basin geometry and geographic extent}

As can be concluded from the above discussion, the fault terminating the Minkinfjellet basin stratigraphy to the west is situated farther east than that of the Ebbadalen basin strata. This would be the case whether or not this fault represented the primary basin margin or a post-Minkinfjellet/pre-Cadellfjellet fault uplift to the west that possibly led to erosion of the Minkinfjellet strata (Figs. 3 and 4).

A peculiar feature of the Minkinfjellet succession, in similarity with the Ebbadalen strata, is the considerable change in thickness (see isopachs in Fig. 1). Close to the fault, at Cheopsfjellet, it is about $50 \mathrm{~m}$, but increases rapidly to ca. $350 \mathrm{~m}$ to the east of Petuniabukta. From there, it decreases slowly eastward and southward to thicknesses of a few tens of metres at Filchnerfonna and southern Billefjorden. Its continuation to the north is, unfortunately, not exposed.

The angular unconformity above the Minkinfjellet succession is very slight and shows overstepping characteristics. This and the considerable facies variations within the succession (sec below) may exclude the idea that the asymmetric geometry of the basin fill could be due to post-Minkinfjellet downwarping and crosion.

Though the strata to the east of Petuniabukta is cut by both normal and reverse faults, none of these seem to be of Middle to Late Carboniferous age. Reverse faults affect the entire Carboniferous strata (Fig. 5) and are probably of Tertiary age, while most normal faults do not proceed higher than into the Lower Carboniferous and are overlain by the undeformed Ebbadalen succession. Some of thesc normal faults have probably been reactivated later (Tertiary?), but no deformation structures are unconformably covered by the Cadellfjellet Member of the Nordenskiöldbreen Formation.

The asymmetric basin structure in which the Minkinfjellet succession lies is thus much more pronounced than indicated by earlier authors.

\section{Post-sedimentary tectonics and possible earthquake breccias}

Still, there is evidence for minor faulting soon after the deposition of the Minkinfjellet succession. In several places at the western side of Wordiekammen and at Fortet, peculiar fissures which are filled with chaotic breccias can be observed (Figs. 6 and 7). The fissures dissect the base of the Cadellfjellet Member 

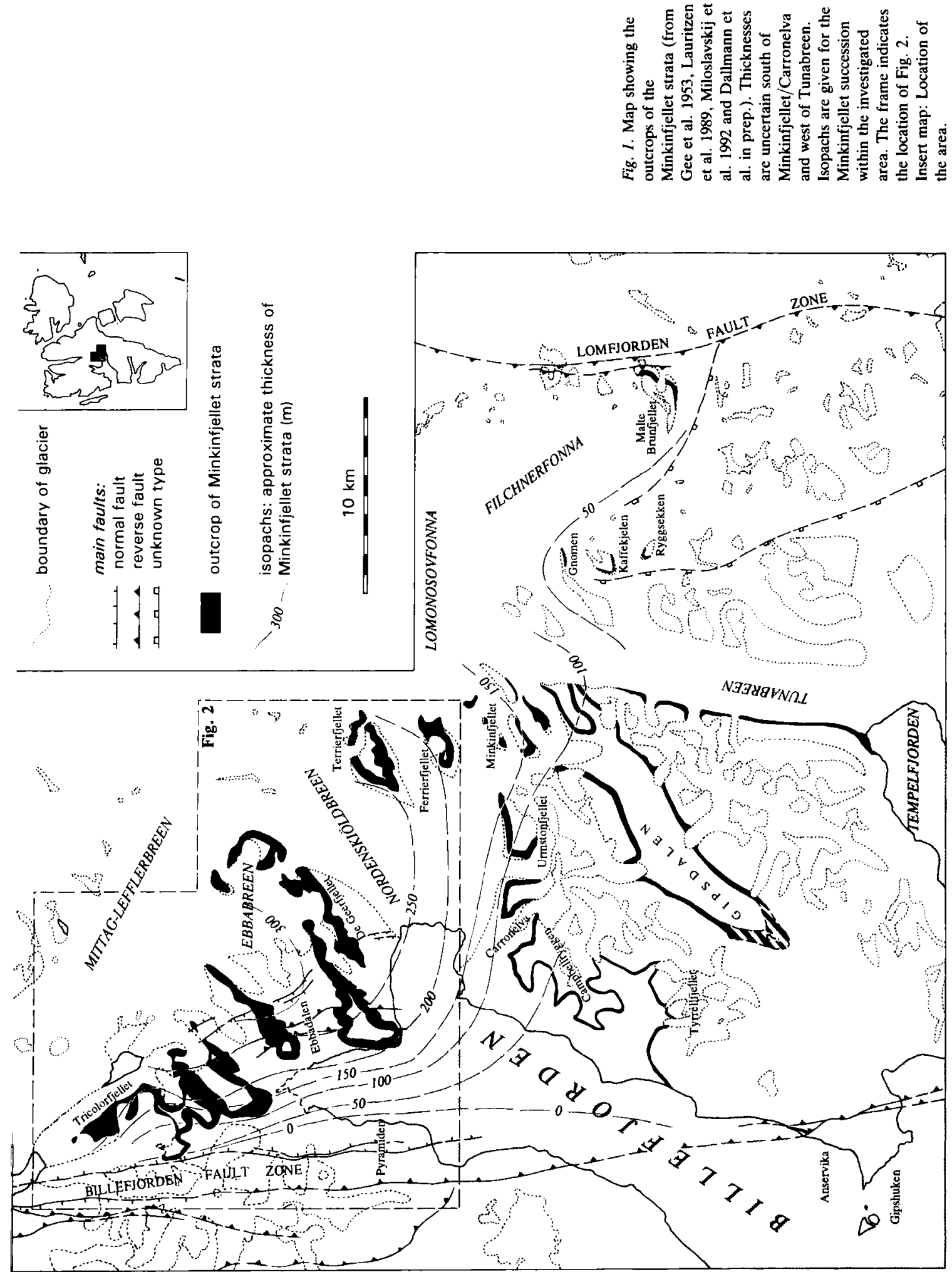


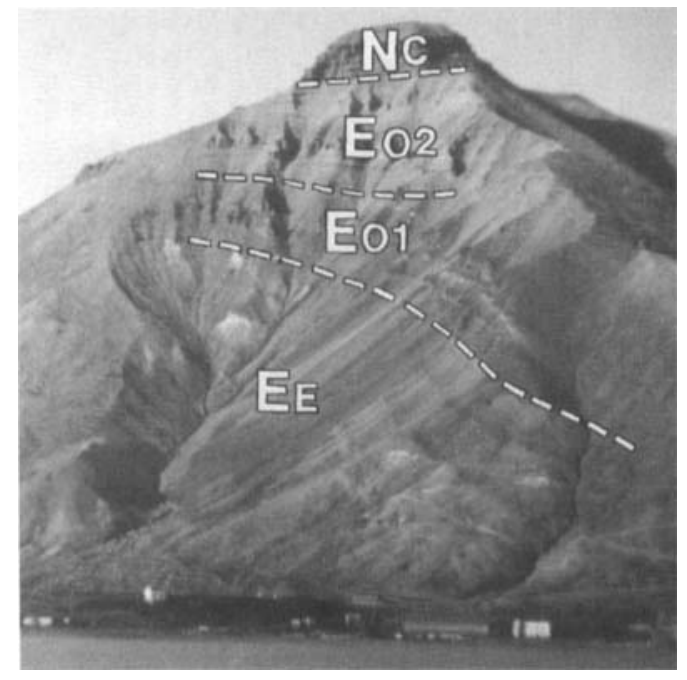

Fig. 2. The mountain Pyramiden with indicated stratigraphic units $(E=$ Ebbadalen Formation; $E E=$ Ebbaelva Member; EO $=$ Odellfjellet Member; $O_{1}=$ red part; $O_{2}=$ light part; $\mathrm{NC}=$ Cadellfjellet Member of Nordenskiöldbreen Formation). Despite carlier published work, there is probably no Minkinfjellet strata in this area.

and are uncomformably overlain by a limestone ca. $20-30 \mathrm{~m}$ higher up. The strata below has locally suffered minor displacements. In one place, the uppermost dissected limestones are broken up and a section has been rotated (Fig. 6). The breccias consist of adjacent carbonate lithologies, i.e both of the upper Minkinfjellet and the lower Cadellfjellet carbonate rocks. They are completely consolidated (Fig. 7). The most rcasonable explanation for these features I can suggest are earthquakes with related fissure formation and minor offsets along the latter.

\section{Stratigraphic subdivision/ nomenclature and facies distribution}

The base of the Minkinfjellet succession is an apparently paralle! stratigraphic unconformity; it is defined by a straight, lithologically distinct bed boundary throughout the outcrop area, while both the Minkinfjellet and the underlying Ebbadalen successions, respectively, are characterized by lateral facics changes with interfingering of their lithological facies (members). Most member boundaries are, at a regional scale, diachronous zig-zag planes arranged obliquely to the formation boundaries (i.e. bases of Ebbadalen, Minkinfjellet and Cadellfjellet successions)
It is thus reasonable to address the Minkinfjellet succession as an individual basin sequence and to raise it from a member to a formation rank. Like the Ebbadalen strata, the Minkinfjellet strata have also been deposited in a fault-bounded basin, have a comparable thickness range and a complex lithological variety that needs a subdivision into members. This succession should be excluded from the platform-like deposits of the Nordenskiöldbreen Formation and be called the Minkinfjellet Formation*, though facies transitions occur in eastern areas, where the Minkinfjellet succession is comparatively thin.

Cutbill \& Challinor (1965) subdivided their Minkinfjellet "Member" into the Carronelva, Elsabreen, Anservika and Pyramiden beds. As argued above, the Pyramiden beds (not defined by the authors, but probably identical with the "Pyramiden conglomerate" of Gee et al. 1953) perform the laterally interfingering westward continuation of the Ebbadalen Formation (Gjelberg \& Steel 1981; Johannessen 1980; Johannessen \& Steel 1992). The Elsabreen beds are similarly defined, though in a place a little farther north. The only explanation I can offer after having mapped the area is that these two successions are identical. The Carronelva and Anservika beds, both defined in places east of Billefjorden, have distinct characteristics and should be raised to member rank. For another distinct lithology that occurs in western parts of the Minkinfjellet basin, I would like to propose the name "Fortet Member".

Carronelva Member (Figs. 5, 8 and 9). - The Carronelva Member forms the lower part of the Minkinfjellet succession in central and northern parts of the basin. It underlies the breccias of the Fortet Member near Petuniabukta and the carbonate rocks of the Anservika Member. In eastern areas it may consist of only a few metres of red beds or multicoloured clastic rocks (shales, sandstones and conglomerates), either below Anservika limestones (Malte Brunfjellet) or as the only representative of the Minkinfjellet basin succession (Gnomen). At Ebbabreen and Ragnarbreen the Carronelva Member also starts with coarse clastic rocks at the base (polymict sedimentary breccias with a carbonate matrix). These basal beds pinch out westward where they are replaced by greenish to yellowish medium-grained sandstones (western half of Sfinksen, Løvehovden and Wordiekammen). The overlying succession consists of yellowish sandstones, locally with a distinct sulphurous smell. Shales, marls, limestones and sandy limestones with gypsum vugs are intercalated in the upper part, where a complex interfingering of lithologies between the Anservika and Carronelva Members occurs. Gypsum layers occur in the type locality at Carronelva, south of Nordenskiöldbreen (Cutbill \& Challinor 1965). The thickness at the type locality is $41 \mathrm{~m}$, while it attains more than $100 \mathrm{~m}$ in Ebbadalen and Ragnardalen.

Anservika Member (Figs. 5, 8 and 9). - The Anservika Member consists of dolomites, limestones and fine-grained limestone conglomerates and occurs mainly in eastern and southern areas, but also in the upper levels of the central and northern basin areas between Adolfbukta and Terrierfjellet. In places, it comprises most of the basin succession, e.g. Anservika, Minkinfjellet, Terrierfjellet, Flemingfjellet, Malte Brunfjellet, though thin clastic beds of the Carronelva Member may lie below it. The carbonate rocks are interlayered with marls or marly limestones which often give the succession a distinctly stratified appearance. They are more massive and rich in flint concretions or flintstone intercalations in the west at Petuniabukta. A few gypsum layers are intercalated in their lower

* The formal stratigraphic nomenclature of Svalbard is recently being elaborated by the Committec on the Stratigraphy of Svalbard (SKS). The revision proposed here has been formally submitted to the committec for consideration. 

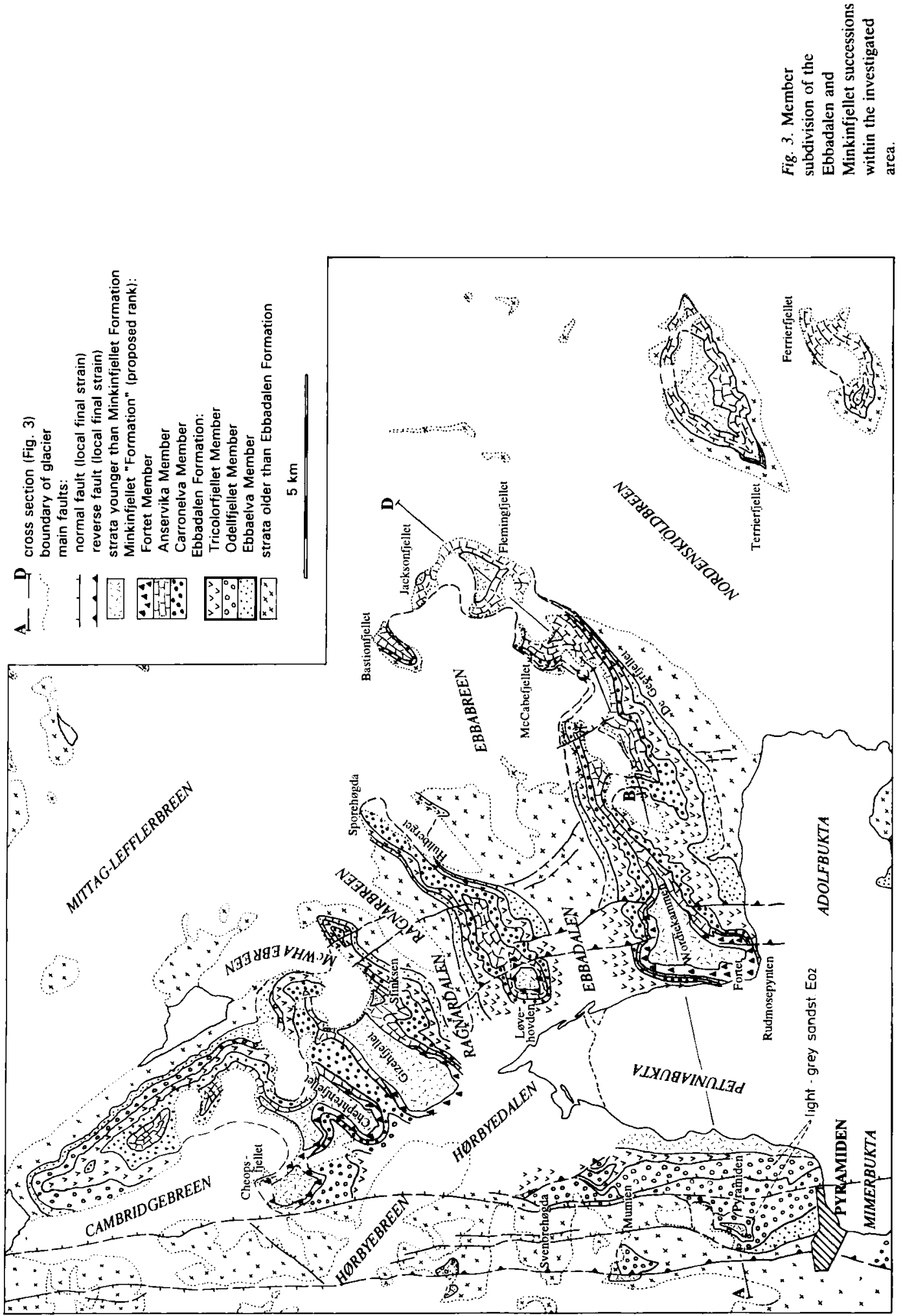

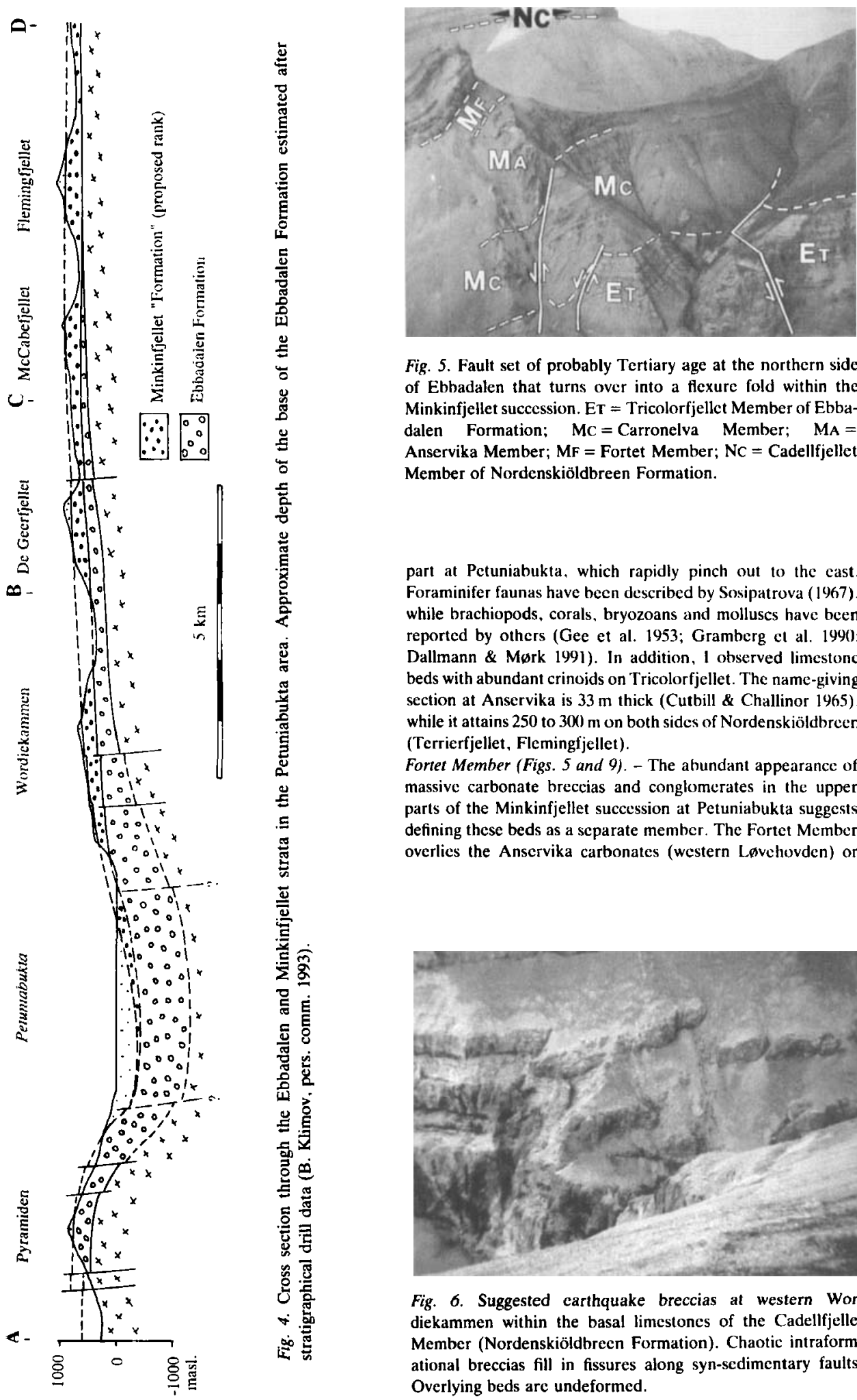

Fig. 5. Fault set of probably Tertiary age at the northern side of Ebbadalen that turns over into a flexure fold within the Minkinfjellet succession. ET $=$ Tricolorfjellet Member of Ebbadalen Formation; $\quad \mathrm{MC}=$ Carronelva Member; $\quad \mathrm{MA}=$ Anservika Member; $\mathrm{MF}=$ Fortet Member $; \mathrm{NC}=$ Cadellfjellet Member of Nordenskiöldbreen Formation.

part at Petuniabukta, which rapidly pinch out to the cast. Foraminifer faunas have been described by Sosipatrova (1967), while brachiopods, corals, bryozoans and molluscs have been reported by others (Gee et al. 1953; Gramberg et al. 1990; Dallmann \& Mork 1991). In addition, I observed limestone beds with abundant crinoids on Tricolorfjellet. The name-giving section at Anservika is $33 \mathrm{~m}$ thick (Cutbill \& Challinor 1965), while it attains 250 to $300 \mathrm{~m}$ on both sides of Nordenskiöldbreen (Terrierfjellet, Flemingfjellet).

Fortet Member (Figs. 5 and 9). - The abundant appearance of massive carbonate breccias and conglomerates in the upper parts of the Minkinfjellet succession at Petuniabukta suggests defining these beds as a separate member. The Fortet Member overlics the Anservika carbonates (western Lovehovden) or

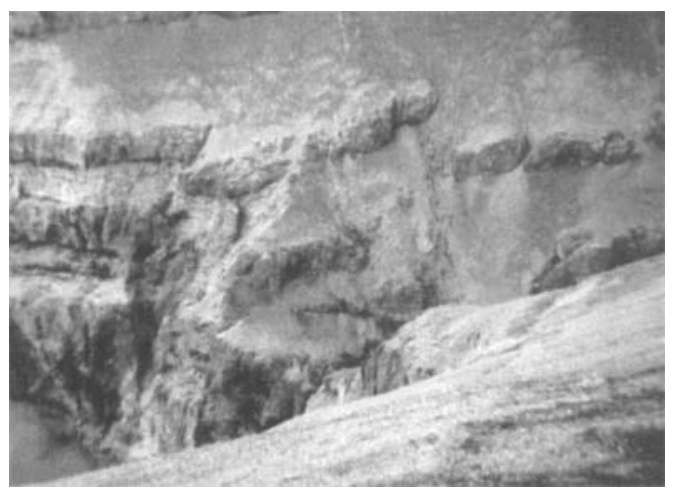

Fig. 6. Suggested earthquake breccias at western Wordiekammen within the basal limestones of the Cadellfjellet Member (Nordenskiöldbrecn Formation). Chaotic intraformational breccias fill in fissures along syn-sedimentary faults. Overlying beds are undeformed. 


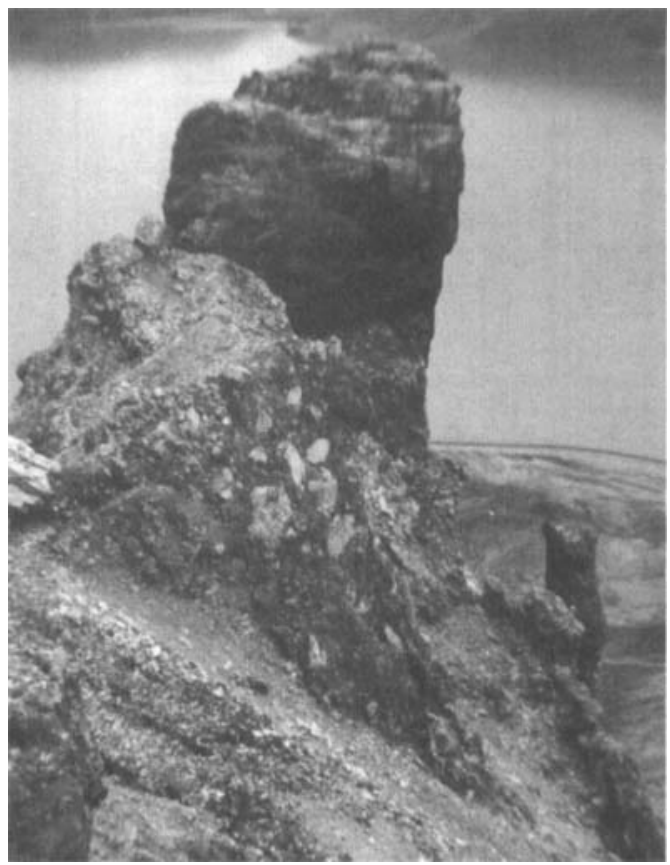

Fig. 7. Suggested carthquake breccias at Fortet. Stratigraphic position as in Fig. 6 . The intraformational breccias cut vertically through the strata.

replaces them (Cheopsfjellet, western Wordiekammen). The breccias are intraformational and contain unsorted carbonate clasts seldom exceeding diametres of $10 \mathrm{~cm}$. They may locally represent in-situ brecciated bedrock, but consist of distinctly transported clasts in other places. Both grain-supported and matrix-supported varicties occur, with a micritic carbonate matrix. The rocks show different degrees of cementation, so that well-cemented parts tend to form cliffs and pinacles. while the surrounding material is removed by erosion. The exposures

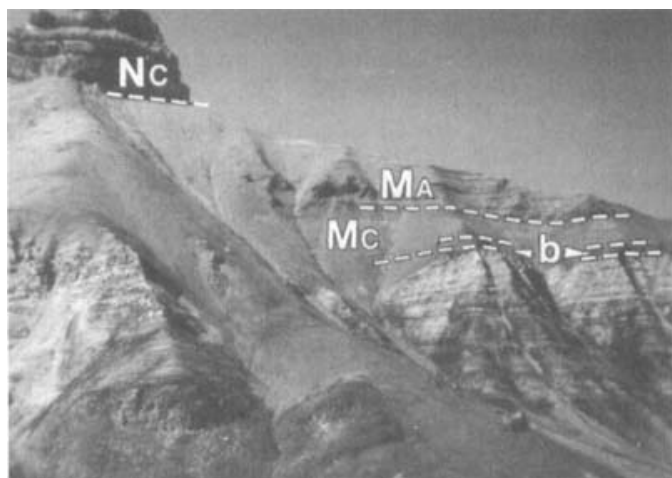

Fig. 8. Minkinfjellet strata on the northern side of Ragnarbreen: A basal scdimentary breccia (b) is overiain by a sandstoncdominated succession grading upward into sandstone-limestone alternations ( $\mathrm{MC}=$ Carronelva Member) and overlying limestones with a few eastward attenuating gypsum beds in its lower part $\left(\mathrm{MA}_{\mathrm{A}}=\right.$ Anservika $\left.\mathrm{Mcmber}\right)$. NC $=$ Cadellfjellet Member of Nordenskiöldbreen Formation.

on the southern side of Fortet, near Rudmosepynten, are well suited as a type section for the Fortet Member. In this place. the thickness is ca. $240 \mathrm{~m}$, which is about the maximum observed thickness.

\section{Concluding remarks}

The Middle Carboniferous Minkinfjellet "Member" lies in an asymmetric basin structure with distinctly westward increasing clastic inlux. The succession attenuates towards the south and east, where carbonate lithologies dominate (the northern continuation is not exposed).

A rock succession exposed west of Billefjorden. situated within the Billefjorden Fault Zone, has previously been assigned to the Minkinfjellet "Member" though it most probably forms

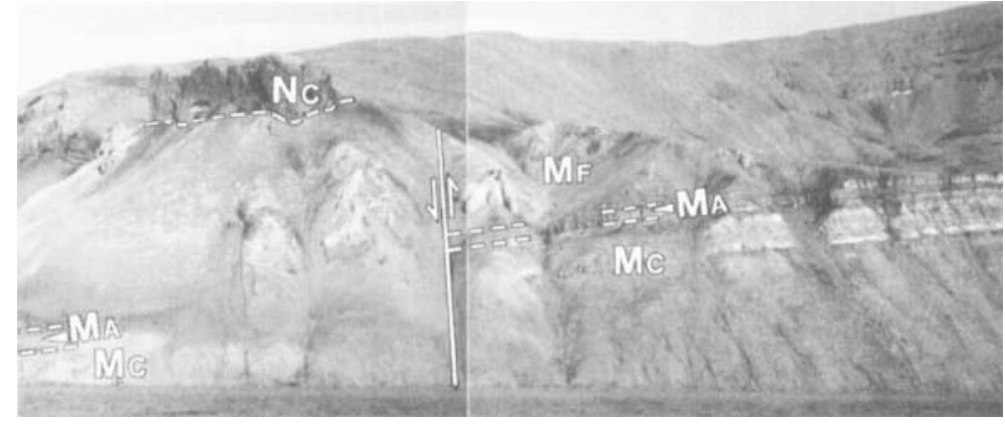

Fig. 9. Fortet, southwestern Wordikammen. 10-12 m of dark Anservika limestone (MA) between thick successions of the underlying Carronelva Member (MC), predominantly sandstone and shales) and the overlying Fortet Member (MF, limestone breccias). NC = Cadellfjellet Member of Nordenskiöldbreen Formation. 
part of the underlying Ebbadalen Formation. Minkinfjellet strata do not occur west of Billefjorden. Both the base and the top of the Minkinfjellet basin strata arc stratigraphic unconformitics.

The subdivision of the Minkinfjellet strata is proposed to be extended. The Minkinfjellet succession, formerly defined as a member of the Nordenskiöldbreen Formation, is proposed to be raised to formation rank due to its individual basin character, similar to the underlying Ebbadalen Formation. Few details from the Minkinfjellet Basin are known. Further investigations such as stratigraphical logging, facies analyses and paleontological age determinations are needed in order to understand the development of the basin.

Acknowledgements. - I would like to express my thanks to E. Johannessen (Statoil, Stavanger) for critical comments that improved the manuscript.

\section{References}

Cutbill, J. L. \& Challinor, A. 1965: Revision of the stratigraphical scheme for the Carboniferous and Permian rocks of Spitsbergen and Bjørnøya. Geol. Mag. 102, 418-439.

Dallmann, W. K. \& Mørk, A. (cds.) 1991: Stratigraphical dictionary of Svalbard. Translation from the Russian title: Stratigrafičeskij slovar' Špicbergena (Gramberg. I. S., Krasil'šcikov, A. A.\& Semevskij, D. V., Eds., 1990). Norsk Polarinst. Rapp. 74, 1-189.

Forbes, C. L., Harland, W. B. \& Hughes, N. F. 1958: Palcontological evidence for the age of the Carboniferous and Permian rocks of central Vestspitsbergen. Geol. Mag. 95, 463490.

Gec, E. R., Harland, W. B. \& McWhae, J. R. H. 1953: Gcology of central Vestspitsbergen. Part I: Review of the geology of Spitsbergen with special reference to central Vestspitshergen. Trans. Royal Soc. Edinburgh 52 (9), 299-356.

Gjelberg, J. \& Steel, R. J. 1981: An outline of Lower-Middle Carboniferous sedimentation on Svalbard: effects of climatic, tectonic and sea level changes in rift basin sequences. In Kerr.
J. W. \& Fergusson, A. J.: Geology of the North Atlantic Borderlands. Can. Soc. Petrol. Geol. Mem. 7, 543-561.

Gramberg, I. S., Krasil'šcikov, A. A. \& Semevskij, D. V. (eds.) 1990: Stratigraficeskij slovar' Spicbergena (Stratigraphical dictionary of Sualbard). NEDRA, Leningrad. Pp. 1-203.

Harland, W. B., Cutbill, J. L., Friend, P. F., Gobbett, D. J., Holliday, D. W., Maton, P. I., Parker, J. R. \& Wallis, R. H. 1974: The Billefjorden Fault Zone, Spitsbergen - the long history of a major tectonic lineament. Norsk Polarinst. Skr. $161,1-72$.

Johannessen, E. P. 1980: Facies analysis of the Ebbadalen Formation, Middle Carboniferous, Billefjorden Trough. Spitsbergen. Cand. real. thesis, University of Bergen. Pp. 1-314.

Johannessen, E. P. \& Steel, R. J. 1992: Mid-Carboniferous extension and rift-infill sequences in the Billefjorden Trough, Svalbard. In Dallmann, W. K., Andresen, A. \& Krill, A. (eds.): Post-Caledonian tectonic evolution of Svalbard. Norsk Geol. Tidsskr. 72 (1), 35-48.

Lauritzen, Ø., Salvigsen, O. \& Winsnes, T. S. 1989: Geological map of Svalbard 1:100,000, Sheet C8G Billefjorden. Norsk Polarinst. Temakart No. 5.

Ljutkevix, E. M. 1937: Geologija treticnich uglenosnych otloZenij Špicbergena rajona Ajs-Fiorda. (Geology of the Tertiary coal-bearing deposits of Spitsbergen, Isfjorden area.) NIIGA, Trudy 76.

Miloslavskij, M. Ju., Birjukov, A. S., Šlēnskij, S. N. \& Dallmann, W. K. 1992: Geological map of Sualbard 1:100,000, preliminary edition, sheet D8G Negribreen. Norsk Polarinstitutt.

Nordenskiöld, A. E. 1875: Utkast till Isfjordens och Belsounds geologi. Geoligiska Föreningens $i$ Stockholm Förhandlingar Bd. 2, 243-260, 301-322, 356-373.

Sosipatrova, G. P. 1967: Verchnepaleozojskie foraminifery Špicbergena. (Upper Paleozoic foraminifers of Spitsbergen.) In: Materialy po stratigrafii Spicbergena. Leningrad.

Ustrickij, V. I. 1967: Osnovynye certy stratigrafii i paleogeografii verchnego paleozoja Špicbergena. (Main stratigraphical and paleogeographical features of the Upper Paleozoic of Spitsbergen.) In: Materialy po stratigrafii Śpicbergena. Leningrad.

Wordie, J. M. 1919: Report on the Carboniferous exposures north of Adolf Bay (Spitsbergen). Scottish Spitsbergen Syndicate Papers. 